\title{
Study on Vocabulary Learning Strategies for Chinese English-Majored Graduates
}

\author{
You-gen Lou \\ School of Foreign Studies Yangtze University Hubei Province, China
}

\begin{abstract}
This paper attempts to explore the overall pattern of English vocabulary learning strategies used by some Chinese English-majored graduates. In addition, both similarities and differences in English vocabulary strategies used between male English-majored graduates and female English-majored graduates. 85 first-year English-majored graduates from China Three Gorges University and Yangtze University participated in a vocabulary test and a questionnaire. The results showed: (1) Chinese Englishmajored graduates used a variety of English vocabulary learning strategies(EVLS) in vocabulary learning, including metacognitive, cognitive and social/affective strategies. (2)There were significant differences in using EVLS at metacognitive, social/affective levels between male English-majored graduates and female Englishmajored graduates.
\end{abstract}

Index Terms - Chinese English-majored Graduates, Learning Strategies, English Vocabulary Learning Strategies

\section{Introduction}

As we all know, one can master the grammar of the target language in the limited time, while one cannot grasp the vast vocabulary of one's native or a foreign language.

Vocabulary learning is the greatest stumbling block for most language learners. As an indispensable part of language system, vocabulary learning is of great importance to language acquisition. Vocabulary is a very important component of a language. One cannot learn a language without vocabulary (Krashen, S. 1989). The study of vocabulary is at the center of language learning and teaching. In a language, grammar provides the overall patterns, vocabulary the material to put in the patterns. No matter how well the student learns grammar, no matter how successfully he masters the sounds of a second language without words to express a wide range of meanings, communication in that language cannot reach any meaningful way. And Wilkins (1972) observes "without grammar very little can be conveyed; without vocabulary nothing can be conveyed."

The purpose of this study was to investigate the vocabulary learning strategies used by Chinese Englishmajored graduates and their relationship to learning outcomes. More specifically, this study attempted to answer the following questions:

1) What types of strategies do Chinese English-majored graduates tend to employ in learning vocabulary?

2) Are the vocabulary learning strategies used by male English-majored graduates different from those used by female English-majored graduates?

\section{Literature Review}

Research on learning strategies can be divided into three stages. The first stage concerns with identifying and listing all the strategies that foreign language learners used in their learning. In the second stage, researchers focus on classifying and giving definitions to strategies. The third stage deals with the effectiveness of learning strategies with their results most fascinating because there are many classifications and definitions.

The literature on learning strategies in foreign language learning emerged from a concern for identifying the characteristic of effective learners. Research focusing on the "good language learners" had identified strategies reported by students or observed in language learning situations that seemingly contributed to learning. These efforts demonstrated that students do apply learning strategies while learning a foreign language and these strategies can be described and classified. Therefore, many researchers (Naimen, N., M..Frohlich, \& A. Todesco. 1975; Rubin, J. 1985; O’Malley, J.\&A. Chamot, 1990) studied the identification and classification of learning strategies.

Influenced strongly by the findings of cognitive psychology, O'Malley and Chamot (OMalley, J.\&A. Chamot, 1990) considered learning strategies as cognitive skills. Learning strategies have been divided into three categories according to the level or type of processing involved (O’Malley, J. \& A.Chamot, 1990). They are meta-cognitive strategies, cognitive strategies, and social/affective strategies. Meta-cognitive strategies are higher order executive skills that may entail planning for, monitoring, or evaluating the success of a learning activity. Cognitive strategies operate directly on incoming information, manipulating it in ways that enhance learning. Social/affective strategies represent a broad grouping that involves either interaction with another person or ideational control over affect.

\section{Research Methods}

\section{A. Subjects}

In September 2011， 85 first-year English-major graduates were in the school of foreign studies from China Three Gorges University and Yangtze University responded to the vocabulary test and the Vocabulary Learning Strategies Questionnaire. Among the 85 subjects, 70 were females and 15 males, average age 23 with Chinese as the main language.

\section{B. Instruments}

The instruments used in the study were the vocabulary test and the Vocabulary Learning Strategies Questionnaire. 
Tab 1. the greatest differentiation and heaviest use in subcategories of planning strategies.

\begin{tabular}{|c|c|}
\hline Learning Strategies & Description \\
\hline \multicolumn{2}{|l|}{ Metacognittive } \\
\hline Advanced organizers & Making a general but comprehensive preview of the concept or principle in an anticipated learning activity. \\
\hline Direct attention & Deciding in advance to attend in general to a learning task and to ignore irrelevant distracters. \\
\hline Selective attention & $\begin{array}{l}\text { Deciding in advance to attend specific aspects of language input or situational details that will cue the retention of } \\
\text { language input. }\end{array}$ \\
\hline Advance preparation & Planning for and rehearsing linguistic component necessary to carry out an upcoming language task. \\
\hline Self-monitoring & $\begin{array}{l}\text { Correcting one's speech for accuracy in pronunciation, grammar, vocabulary, or for appropriateness related to the setting } \\
\text { or to the people who are present. }\end{array}$ \\
\hline Delayed production & Consciously deciding to postpone speaking to learn initially through listening comprehension. \\
\hline Self-evaluation & Checking the outcomes of his language learning against an internal measure of completeness and accuracy. \\
\hline \multicolumn{2}{|l|}{ Cognitive } \\
\hline Repetition & Imitating a language model, including overt practice and silent rehearsal. \\
\hline Recoursing & Defining or expanding a definition of a word or concept through use of target reference material. \\
\hline Deduction & Consciously applying rules to produce or understand the second language. \\
\hline Imagery & Relating new information to visual concepts in memory via familiar easily retrievable visualization, phrases, or locations. \\
\hline Auditory representation & Retention of the sound for a word or phrase, or longer language sequence. \\
\hline Key word & $\begin{array}{l}\text { Remembering a new word in the second language by: 1) identifying a familiar word in the first language that sounds like } \\
\text { or otherwise resembles the new word; 2) generating easily recalled images of some relationship with the new word. }\end{array}$ \\
\hline Contextualisation & $\begin{array}{l}\text { Placing a word or phrase in a meaningful language sequence. } \\
\text { Elaboration Relating new information to other concepts in memory. }\end{array}$ \\
\hline Elaboration & Relating new information to other concepts in memory. \\
\hline Transfer & Using previously acquired linguistic and/or conceptual knowledge to facilitate a new language learning task. \\
\hline Inferencing & Using available information to guess meanings of new items, predict outcomes, or fill in missing information. \\
\hline \multicolumn{2}{|l|}{ Social/affective } \\
\hline
\end{tabular}

\section{1) Vocabulary Test}

The author had intended to design all parts of the vocabulary test by himself but found it very difficult. It may take a long time. So the author chose vocabulary from A Modern English Course (published by Foreign Language Teaching and Research Press). The vocabulary test was held in class for students to complete in 30minutes.

\section{2) Questionnaire}

The Vocabulary Learning Strategies Questionnaire, written in Chinese, consists of two parts: One is concerned with personal profiles that is: name, age, and sex, major. The other part consists of 20 statements concerning vocabulary learning behaviors, which are divided into three major parts: metacognitive strategies, cognitive strategies and social/affective strategies. The students indicated their opinions in terms of a five-point scale from 'this statement is never or almost never true of me' (1) to 'this statement is completely or almost completely true of me '(5). The design of the questionnaire is based on O'Malley and Chamot's (1990) classification of learning strategies[5]. Questionnaires were distributed to students and completed in class. We collected 105 valid questionnaires.

\section{Data Collection and Analyses Procedures}

Data collection was conducted through the questionnaire and the vocabulary test. The questionnaires were written in Chinese and handed out to the students during the class session so as to save time and avoid ambiguity in understanding, and if any, the teachers would be of help. The vocabulary test was given to them immediately after the questionnaires were finished and then the two parts are collected. Scores were summed up according the total number of participants' correct responses in the test.

The results of the questionnaire and scores tests were inputted to computer and SPSS14.0 statistical analysis was adopted to make analyses. Descriptive statistics was obtained to summarize the overall patterns of vocabulary learning strategies used by these students. Thereupon, a T-test was performed to examine the differences in using vocabulary learning strategies between male English-majored graduates and female English-majored graduates. The answers to the strategies listed in the questionnaire were designed in 5point Likert-Scale. A mean score above 3 indicates high frequency in the use of the corresponding strategy while a mean score below 3 represents low frequency. 


\section{Results and Analyses}

\section{A. Results of English Vocabulary Learning Strategies}

The first investigated question is what the whole pattern of EVLS employed by Chinese English-majored graduates investigated. The questionnaire is a Five-point scale, so a mean score which is above 3 indicates high frequency in the use of corresponding strategy while a mean score is below 3, which represents low Frequency in the use of the strategy. The higher the mean score is, the more often the strategy is used. In order to determine how they avail themselves to each vocabulary learning strategy, average mean score and standard deviation and strategies use at three levels are calculated (see Table 1 and Table 2)

Table1 showed that the general descriptive statistics of metacognitive strategies, cognitive strategies and social/affective strategies. Among the three dimensions of English vocabulary learning strategies, metacognitve strategies $(M=3.77, S . D=1.23)$, which meant that Englishmajored graduates often adopted metacognitive strategies to help themselves to learn English vocabulary; then cognitive strategies $(M=3.10, S . D=1.02)$ which meant that Englishmajored graduates often used cognitive strategies. Yet social/affective strategies ranks lowest $(\mathrm{M}=2.89, \mathrm{~S} . \mathrm{D}=1.35)$, which suggests that English-majored graduates adopt less social/affective strategies to help themselves to learn English vocabulary.

Table 1 Mean and standard deviation of metacognitve strategies, cognitive strategies and social/affective strategies

\begin{tabular}{|c|c|c|}
\hline Dimensions & M & S.D. \\
\hline Metacognitive Strategies & 3.77 & 1.23 \\
\hline Cognitive Strategies & 3.10 & 1.02 \\
\hline Social/Affective Strategies & 2.89 & 1.35 \\
\hline
\end{tabular}

And Table 2 showed that the descriptive statistics on the use of each strategy at the three dimensions.

Firstly, at metacognitive Level, it was obvious that selective attention( $\mathrm{M}=3.58, \mathrm{~S} . \mathrm{D}=1.03$ ) was the highest rank among the four categories of metacognitve strategies, which indicated that the investigated subjects were positive with regard to learned words and thus sparking their consciousness to acquire them. Learner autonomy $(\mathrm{M}=3.28, \mathrm{~S} . \mathrm{D}=1.04)$, English-majored graduates can learn English vocabulary autonomy. Planning ( $M=3.20$, S.D=1.03), which meant English-majored graduates often planed their English vocabulary learning. Self-evaluation $(M=3.09$, S.D=1.07) meant English-majored graduates can evaluate their English vocabulary learning. Reasons to account for the Englishmajored graduates metacognitive strategies were that Englishmajored graduates were totally adults who knew how to put their attention to learn English vocabulary autonomy without pushing them to learn, and make a plan to learn vocabulary then evaluate their learning procedure by themselves.

Secondly, at cognitive strategies level, from Table 2, we can see that the rank order of English vocabulary learning strategies at cognitive level was translation strategy, dictionary looking-up strategy, repetition strategy, word formation strategy, contextualization strategy, imagery strategy, grouping strategy, keyword strategy. It was evident that contextualization $(M=3.75, S . D=1.01)$ ranked the highest among all the English vocabulary learning strategies at cognitive stage, in other words, which means that Englishmajored graduates used context the most frequent strategy to learn English vocabulary. Next followed by translation, dictionary looking-up appeared as the second frequently used cognitive strategy, which meant that English-majored graduates often learn the new words with the help of a dictionary. The strategy keyword $(\mathrm{M}=2.19$, $\mathrm{S} . \mathrm{D}=1.06)$ suggested that graduates seldom used it to learn vocabulary, although the strategy was popular for more students in west to learn English vocabulary.

Finally, Social/Affective strategies were concerned, group work $(\mathrm{M}=3.16, \mathrm{~S} . \mathrm{D}=.94)$ ranks higher than affective control ( $\mathrm{M}=3.06$, S.D=0.99). English-majored graduates could be as a group to discuss a topic.

The results are generally agreed with those of $\mathrm{Gu}$ and Johson's (Gu, P. Y. \& R. K. Johnson. 1996) study except the following parts: one is the present study shows that Englishmajored graduates investigated are more positive in using the metacognitive strategy-selective attention than learner autonomy at metacognitive strategy, which is in contrast with $\mathrm{Gu}$ and Johson's study; the other is that the present study indicates that rote learning strategies(repetition) plays an important role in students' vocabulary learning process while $\mathrm{Gu}$ and Johson's study suggests that students don't value rote learning as highly as other strategies. The difference may result from the difference of the investigated subjects.

The results of the present study show that students use the mother language as the mediator (translation) to acquire the new words and seem to look down on the value of keyword strategy.

Table 2 Mean and standard deviation of strategies use at three levels

\begin{tabular}{|c|c|c|c|}
\hline Dimensions & Categories & M & S. D. \\
\hline \multirow{4}{*}{$\begin{array}{c}\text { Metacognitie } \\
\text { Strategies }\end{array}$} & Selective attention & 3.58 & 1.04 \\
\hline & Learner autonomy & 3.20 & 1.03 \\
\hline & Planning & 3.10 & 1.18 \\
\hline & Self-evaluation & 3.09 & 1.07 \\
\hline \multirow{8}{*}{$\begin{array}{l}\text { Cognitive } \\
\text { Strategies }\end{array}$} & Word formation & 3.10 & 1.03 \\
\hline & Dictionary Looking-up & 3.71 & 1.05 \\
\hline & Keyword & 2.19 & 1.06 \\
\hline & Grouping & 3.07 & 1.05 \\
\hline & Imagery & 2.81 & 1.04 \\
\hline & Repetition & 3.18 & 1.27 \\
\hline & Translation & 3.01 & 1.15 \\
\hline & Contextualization & 3.75 & 1.01 \\
\hline \multirow{2}{*}{$\begin{array}{c}\text { Social/Affective } \\
\text { Strategies }\end{array}$} & Group work & 3.16 & .94 \\
\hline & Affective control & 3.06 & .99 \\
\hline
\end{tabular}




\section{B. Results of T-test}

All the data from the questionnaires were typed and checked, we used SPSS+14.0 to calculate the mean scores and confirmed that the data were of or close to normal distribution. Then we carried out the independent sample ttest to measure the significant differences in metacognitive strategies, cognitive strategies and social/affective strategies between the female English-majored graduates and the male English-majored graduates. The significant differences occur only when the probability $(\mathrm{P})$ is below or equal to .005 .

Table 3 results of t-test

\begin{tabular}{|c|c|c|}
\hline \multirow{4}{*}{ Meta. } & Learners Strategies & Sig(2-tailed) P \\
\hline & Selective attention & .875 \\
\cline { 2 - 3 } & Learner autonomy & $.003^{* *}$ \\
\cline { 2 - 3 } & Planning & $.004^{* *}$ \\
\hline \multirow{7}{*}{ Cog. } & Self-evaluation & .006 \\
\cline { 2 - 3 } & Word formation & .018 \\
\cline { 2 - 3 } & DictionaryLooking-up & .778 \\
\cline { 2 - 3 } & Keyword & .808 \\
\cline { 2 - 3 } & Grouping & .091 \\
\cline { 2 - 3 } & Imagery & .069 \\
\cline { 2 - 3 } & Repetition & .893 \\
\cline { 2 - 3 } & Translation & .696 \\
\hline \multirow{7}{*}{ Soc./Aff. } & Contextualization & .075 \\
\cline { 2 - 3 } & Group work & $.002^{* *}$ \\
\hline & Affective control & \\
\hline
\end{tabular}

From Table 3, we can see that 1) at the metacognitive level, the strategy of selective attention $(\mathrm{P}=.975)$, there was no significant difference, indicating that graduates from the male and female groups both used this strategy. In the strategy of learner autonomy( $\mathrm{P}=.003)$, which meant there was a significant difference between the male and female groups, indicating that male English-majored graduates and female English-majored graduates had difference in learning autonomy. In the strategy of planning $(\mathrm{P}=.004)$ and the strategy of self-evaluation $(\mathrm{P}=.006)$ were of significant differences. Therefore, we can conclude that female Englishmajored graduates used more strategies when they learn
English vocabulary.2) Using strategies is at the cognitive level. In the strategies of word formation $(\mathrm{P}=.018)$, dictionary looking-up $(\mathrm{P}=.678)$, keyword $(\mathrm{P}=.708)$, grouping $(\mathrm{P}=.091)$, imagery $(\mathrm{P}=.069)$, repetition $(\mathrm{P}=.893)$, translation $(\mathrm{P}=.696)$, contextualization $(\mathrm{P}=.075)$, there are no significant differences between the male and female groups. It indicates that both female and male English-majored graduates use detailed strategies to learn vocabulary.3) at the social/affective level. Both the strategy of group work $(\mathrm{P}=.002)$ and the strategy of affective control $(\mathrm{P}=.001)$ are significant difference, which mean that female English-majored graduates are good at group work to learn vocabulary and good at controlling themselves to learn vocabulary.

\section{Conclusion}

This study was designed to explore the overall pattern of EVLS employed by some English-majored graduates in China. In addition, the employment of strategies and different strategies were used by female English-majored graduates and male English-majored graduates.

85 first-year non-English-majored English-majored graduates from the school of foreign studies in China Three Gorges University and Yangtze University participated in a vocabulary test. And the questionnaire The results showed that (1) Chinese English-majored graduates used a variety of English vocabulary learning strategies in vocabulary learning, including metacognitive, cognitive and social/affective strategies. (2) There were significant differences in using EVLS at metacognitive, social/affective levels between female English-majored graduates and male English-majored graduates.

\section{References}

[1] Gu, P. Y. \& R. K. Johnson. 1996. Vocabulary learning strategies and language learning outcomes. Language Learning 46(4):643-79.

[2] Krashen, S. 1989. We acquire vocabulary and spelling by reading: Additional evidence for the Input Hypothesis. Modern Language Journal 73, 440-464.

[3] Naimen, N., M..Frohlich, \& A. Todesco. 1975. The good language learner. TESL TALK6(1):58-75.

[4] O’Malley,J.\&A.Chamot,1990. Learning strategies in Second Language Acquisition.Cambridge University Press.

[5] Rubin, J. 1985. What the "good language learner" can teach us. TE'SOL Quarterly 9(1):41-51

[6] Wilkins, A. 1972. Linguistics in Language Teaching. Cambridge: MA: MIT Press. 